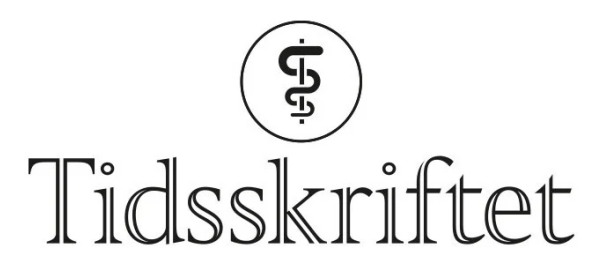

DEN NORSKE LEGEFORENING

\title{
Usunn mytespredning
}

KOMMENTAR

THORLEIF JANSEN

thorleif@kry.no

Thorleif Jansen er spesialist i allmennmedisin og medisinsk sjef i Kry.

Forfatteren har ikke oppgitt noen interessekonflikter.

\section{I en lederartikkel beskriver medisinsk redaktør Øyvind} Stople Sivertsen skvisen fastleger blir satt i når de møter krav og forventninger om å få attest for å få trene på delvis koronastengte treningssenter. I forbindelse med dette skriver han:

"...Og blir man en streng lege, er dynamikken kjent. «Alle andre» får jo lov, så da går pasienten i stedet til en av de andre gruppene som tillates å lage attester. Eller en annen lege, for eksempel en av de mange tilgjengelige engangslegene, der det meste kan løses for de som har penger. Noen velger å se gjennom fingrene med hele problematikken og skriver attest med venstrehånden og regning med gaffel. Slik pragmatikk er god butikk og gjør alle tilsynelatende fornøyde, men vanner samtidig ut hele grunnlaget for at legeattesten tradisjonelt har vært ansett som et verdifullt og anerkjent dokument..."

Forfatteren problematiserer ordningen med krav om attest for å trene, også som et eksempel på stadig ønske og press om å få bruke legeattester som døråpnere i ulike sammenhenger. Dette er en relevant og viktig problemstilling. Det som ikke er greit, er at Tidsskriftet samtidig - og på redaktørplass - bruker sin definisjonsmakt til å male et bilde med bred pensel av en hel gruppe virksomheter - og en hel gruppe leger. Det som er overraskende, er at en organisasjon som til vanlig arbeider kunnskapsbasert, kan tillate seg slike sleivspark i eget tidsskrift.

Vår virksomhet er helprivat. Vi registrerer også økt pågang med ønsker om attester for å trene på treningssenter, og legene som arbeider hos oss opplever også den samme skvisen som Stople Sivertsen beskriver i artikkelen. Men vi har på ingen måte agert slik han frykter at "aktører som oss" skal gjøre. Diskusjonene som har oppstått internt hos oss i forbindelse med dette har resultert i konsensus om at de fleste slike forespørsler blir avvist.

Fordi vi er ansvarlige, og fordi vi etterlever de samme kravene og forventningene som bør stilles til ansvarlige aktører. 
Faglig integritet, høy etisk standard og riktig bruk av fellesskapets ressurser er viktige prinsipper. Det skulle egentlig bare mangle at alle helsevirksomheter holder slike prinsipper høyt. Så må vi erkjenne at det ikke nødvendigvis er alle som har det slik. Men skillelinjen her går ikke skarpt mellom offentlig - eller privat finansierte helsevirksomheter. Gjør kloke valg-kampanjen er eksempel på et konstruktivt initiativ som vi kan forenes om, og som kan bidra til at vi trekker mot samme mål. Generaliserende og sleivete kommentarer i den nevnte artikkelen er et eksempel på det motsatte.

Det jeg etterspør er nyansering fremfor generalisering, og dialog fremfor nedrakking. Samtidig håper jeg at Legeforeningen også aktivt involverer seg i arbeidet med å få frem de viktige nyansene i en viktig debatt. På forhånd takk!

Publisert: 25. mai 2021. Tidsskr Nor Legeforen. DOI: 10.4045/tidsskr.21.0343

(C) Tidsskrift for Den norske legeforening 2023. Lastet ned fra tidsskriftet.no 26. april 2023. 